\title{
DEVELOPMENT OF ALTERNATIVE HPLC METHOD FOR THE DETERMINATION OF TIROFIBAN IN RAT SERUM
}

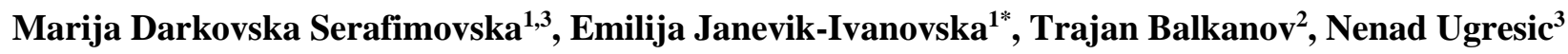 \\ ${ }^{1}$ Faculty of Medical Sciences, Goce Delčev University, Štip, Republic of Macedonia \\ ${ }^{2}$ Faculty of Medicine, Ss. Cyril and Methodius University, Skopje, Republic of Macedonia \\ ${ }^{3}$ Faculty of Pharmacy, University of Belgrade, Belgrade, Serbia \\ e-mail corresponding author???
}

\begin{abstract}
Tirofiban hydrochloride is a reversible antagonist of fibrinogen binding to the GPIIb/IIIa receptor, used for the treatment of acute coronary syndrome. A novel RP-HPLC method has been developed and validated for the determination of Tirofiban in serum of Wistar rats with and without deep acute venous thrombosis. The chromatographic separation was carried out using a reverse-phase HPLC column Purospher ${ }^{\circledR} \mathrm{RP}-18 \mathrm{e}(150 \mathrm{~mm} \times 4.6 \mathrm{~mm}$ i.d.; $5 \mu \mathrm{m})$ coupled with a guard column LiChrosorb ${ }^{\circledR}(4 \mathrm{~mm} \times 4 \mathrm{~mm}$ i.d.; $7 \mu \mathrm{m}$ ) and mobile phase consisting of the mixture of 1-octane sulfonic acid in water ( $\mathrm{pH} 3.0$, adjusted with orthophosphoric acid) and acetonitrile, with a ratio of $60: 40(\mathrm{v} / \mathrm{v})$ and a flow rate of $1.0 \mathrm{ml} / \mathrm{min}$, at a wavelength of $277 \mathrm{~nm}$. The serum concentrations of Tirofiban in the group of rats with DVT were lower than those in the control group, and it could be explained with the binding of Tirofiban with the GPIIb/IIIa receptors.
\end{abstract}

Keywords: Tirofiban; deep acute venous thrombosis (DVT); HPLC determination; rat serum

\section{РАЗВОЈ НА АЛТЕРНАТИВНА НРЦС-МЕТОДА ЗА ОПРЕДЕЛУВАЫЕ ТИРОФИБАН ВО СЕРУМОТ НА СТАОРЕЦ}

Тирофибан хидрохлорид е реверзибилен антагонист на фибриногенот врзувајќи се за рецепторот GPIIb/IIIa, и се користи за третман на акутен коронарен синдром. Нова RP-HPLCметода е развиена и валидирана за определување на тирофибанот во серумот на Wistar стаорци со и без длабока акутна венска тромбоза. Хроматографското раздвојување се врши со помош на реверзно фазна HPLC-колона Purospher ${ }^{\circledR} \mathrm{RP}-18 \mathrm{E}(150 \mathrm{~mm} \times 4.6 \mathrm{~mm} ; 5 \mu \mathrm{m})$ во комбинација со претколона LiChrosorb ${ }^{\circledR}(4 \mathrm{~mm} \times 4 \mathrm{~mm} ; 7 \mu \mathrm{m})$ и мобилна фаза која се состои од смеса на 1-октанска сулфонска киселина во вода ( $\mathrm{pH} 3.0$, се регулира со ортофосфорна киселина) и ацетонитрил во сооднос $60: 40(\mathrm{v} / \mathrm{v})$ и проток од $1,0 \mathrm{ml} / \mathrm{min}$, на бранова должина од $277 \mathrm{~nm}$. Серумските концентрации на тирофибанот во групата стаорци со ДВТ беа пониски од оние во контролната група, што би можело да се објасни со врзување на тирофибанот за рецепторите GPIIb/IIIa.

Клучни зборови: тирофибан; длабока акутна венска тромбоза (ДВТ); HPLC-определување; серум на стаорец

\section{INTRODUCTION}

Tirofiban hydrochloride, chemically described as $\mathrm{N}$-(butylsulfonyl)-O-(4-[4piperidinyl]butyl)-L-tyrosine monohydrochloride monohydrate (Fig. 1), is a reversible non-peptide antagonist of fibrinogen binding to the major platelet surface glycoprotein (GP) IIb/IIIa receptor. In this way Tirofiban inhibits platelet aggregation. GP IIb/IIIa is involved in platelet aggregation using the tripeptide Arg-Gly- 
Asp (RGD) as a template $[1,2]$. When administered intravenously, Tirofiban inhibits ex vivo platelet aggregation in a dose- and concentrationdependent manner. In combination with heparin and aspirin, it is used for the treatment of patients with unstable angina or non-Q-wave myocardial infarction, including patients who are to be managed medically or those treated prior to angiography/coronary intervention [3, 4]. Adjunctive therapy with GP IIb/IIIa-receptor inhibitors can reduce the incidence of cardiac ischemic events, including subsequent myocardial infarction (MI) and death, in patients with non-ST-segmentelevation acute coronary syndromes [5]. It was shown that treatment with Tirofiban can reduce the rate of thrombotic cardiovascular events (combined endpoint of death, myocardial infarction, or refractory ischemia/repeat cardiac procedure) in patients with non-ST elevation acute coronary syndrome (NSTE-ACS) [6, 7]. Ex vivo cultures of arterial rings confirmed that Tirofiban also activate growth-stimulatory signals in the endothelium. Thus, the benefits of tirofiban in those with acute coronary syndromes may be due to rapid endothelization of damaged vessel, besides antiplatelet effects [1]. Platelet aggregation inhibition [8] is reversible following cessation of the infusion of Tirofiban. Tirofiban has a rapid onset and short duration of action when administered intravenously, with a half-life of approximately 2 hours. Also, $90 \%$ inhibition is achieved by the end of a 30 minute infusion [9]. Tirofiban is not strongly bound to plasma proteins. The unbound fraction in human plasma is around 35\%. The distribution volume of Tirofiban in the steady state ranges from 22 to 42 liters [10-12]. Experiments with the intravenous administration of 14C-labelled Tirofiban to healthy subjects show that it is cleared from the plasma largely by renal excretion, with about $65 \%$ of an administered dose appearing in urine and about $25 \%$ in feces $[10,11]$. The drug was approved by the FDA in 1998, discovered by Merck, USA, and marketed under the brand name Aggrastat in the US by Medicure Pharma and the rest of the world by Irokocardio International SARL, Geneva $[2,12,13]$.

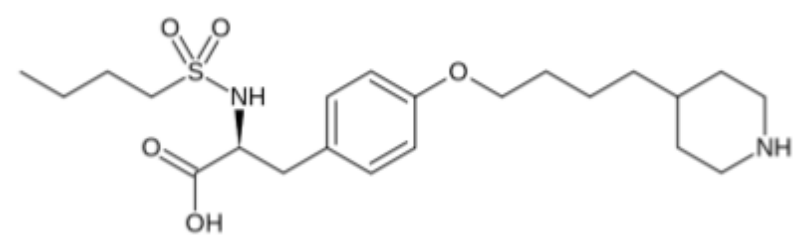

Fig. 1. Chemical structure of Tirofiban hydrochloride
Very few methods have been reported for the determination of Tirofiban in biological samples [14, 15]. According to data in the literature, reverse-phase chromatographic methods with acetonitrile and phosphate buffer solution [16] or 1-octane sulfonic acid solution at lower $\mathrm{pH}$ are used for the identification and quantification of Tirofiban $[15,17]$.

In our previous work, we developed and validated a RP-HPLC method using the mobile phase consisting of phosphate buffer ( $\mathrm{pH} 5.2)$ and acetonitrile $(70: 30, \mathrm{v} / \mathrm{v})$ and a detection wavelength of $274 \mathrm{~nm}$ [16]. Although we obtained good separation with the existing method, we aimed to achieve higher sensitivity and an increased range of measurements. Therefore, our objective was to develop a sensitive, reproducible, rapid, and cost-effective RP-HPLC method with UV detection for the therapeutic monitoring of the levels of Tirofiban in serum samples.

\section{EXPERMENTAL}

\subsection{Chemicals and reagents}

Tirofiban hydrochloride as a Reference Standard was supplied by Merck (batch No. L000700462-006X027). Methanol and acetonitrile were HPLC grade and were provided by Sigma Aldrich. All other chemicals were analytical reagent grade. Redistilled water was used to prepare solutions for mobile phase.

\subsection{Apparatus}

Chromatography was performed on a HPLC system 1200 series equipped with: binary pump SL, microvacuum degasser, standard autosampler ALS SL, column compartment TCC SL, diode array detector DAD SL from Agilent Technologies (Germany).

\subsection{Chromatographic conditions}

The separation was performed at room temperature, using an isocratic method and reversephase HPLC column Purospher ${ }^{\circledR}$ RP-18e (150 mm $\times 4.6 \mathrm{~mm}$ i.d.; particle size $5 \mu \mathrm{m})$ coupled with a guard column LiChrosorb ${ }^{\circledR}(4 \mathrm{~mm} \times 4 \mathrm{~mm}$ i.d.; particle size $7 \mu \mathrm{m}$ ) from Merck KGaA (Darmstadt, Germany). The choice of solvent for the preparation of standard solutions and extraction of Tirofiban from the blood was made considering the solubility of Tirofiban. Tirofiban is highly soluble in methanol. Methanol in the ratio of 3:1 in the blood 
samples precipitated proteins so they do not interfere with further analysis.

The mobile phase, containing a mixture of 1-octane sulfonic acid in water ( $\mathrm{pH} 3.0$, adjusted with orthophosphoric acid) and acetonitrile in the

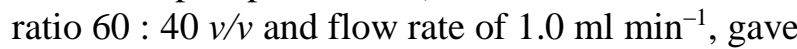
the best separation of peaks without interference from other components from the plasma including heparin, which we added as an anticoagulant.

The injection volume of samples was $50 \mu$. Chromatographic data were analyzed using ChemStation software from Agilent Technologies (Germany), following requirements for chromatographic analysis. Regression calculations were done with Microsoft Excel.

\subsection{Preparation of 1-octane sulfonic acid solution}

Two $\mathrm{g}$ of 1-octane sulfonic acid were weighed and transferred into a 1000-ml flask, and then water was added to the mark. The $\mathrm{pH}$ was adjusted to 3.0 with orthophosphoric acid

\subsection{Standard solutions and calibration curves}

The standard stock solution of Tirofiban was prepared by dissolving Tirofiban hydrochloride with methanol to achieve the concentration of Tirofiban in the range of $0.01-0.21 \mathrm{mg} \cdot \mathrm{ml}^{-1}$. The calibration curve was constructed by plotting the ratio of the peak area of the drug against the drug concentration. All solvents and solutions for HPLC analysis were filtered using a membrane filter $(0.45 \mu \mathrm{m}$ pore size $)$ and were vacuum degassed before use.

\subsection{Validation of the method}

The proposed method was validated according to the guidelines set by the International Conference of Harmonization for validation of analytical procedures $[18,19]$. The precision and reproducibility of the proposed method were evaluated by performing replicate analysis of the standard solutions and serum samples, to determine intraday and inter-day variability [within day $(n=5)$ and between days $(n=5)]$ for three different concentrations. Relative standard deviations were calculated to obtain the precision of the method. The stock solution of Tirofiban was prepared by dissolving $25 \mathrm{mg}$ of Tirofiban reference standard in methanol and diluted with methanol to $25 \mathrm{ml}$. Working standard solutions were prepared by appropriate dilution with methanol to achieve final concentrations of Tirofiban $\left(0.033 \mathrm{mg} \cdot \mathrm{ml}^{-1}, 0.1\right.$ $\mathrm{mg} \cdot \mathrm{ml}^{-1}$ and $0.21 \mathrm{mg} \cdot \mathrm{ml}^{-1}$ ).

\subsection{Recovery studies}

To establish the accuracy and reliability of the proposed method, recovery experiments were carried out by adding known amounts of the standard solution of Tirofiban to rat blood. Serum samples were used for this study and collected from normal rats before introducing the experimental model of deep venous thrombosis (DVT) in order to obtain a validated quantitative method suitable to monitor the concentration of Tirofiban and potential degradation products in vivo after application. Aliquots of $1 \mathrm{ml}$ rat blood samples were spiked with Tirofiban standard solution to achieve final concentrations of Tirofiban: $0.033 \mathrm{mg} \cdot \mathrm{ml}^{-1}$, $0.1 \mathrm{mg} \cdot \mathrm{ml}^{-1}$ and $0.21 \mathrm{mg} \cdot \mathrm{ml}^{-1}$. The heparin was added as an anticoagulant. After heating in a water bath for $15 \mathrm{~min}$., the tubes were centrifuged for 5 $\min$ at $3500 \mathrm{rpm} \mathrm{min}{ }^{-1}$. The supernatant was taken carefully, methanol was added for the precipitation of proteins in the ratio serum:methanol $=1: 3$ and then the tubes were centrifuged again for $5 \mathrm{~min}$ at $3500 \mathrm{rpm} \mathrm{min}^{-1}$. The recoveries were calculated after five repeated experiments. The amount of Tirofiban in spiked rat serum samples was calculated from the linear regression equation.

\subsection{Limit of detection and limit of quantification}

The limit of detection (LOD) and limit of quantitation (LOQ) were calculated using following formula: $\mathrm{LOD}=3.3 \mathrm{SD} / \mathrm{S}$ and $\mathrm{LOQ}=10$ $\mathrm{SD} / \mathrm{S}$, where $\mathrm{SD}$ is the standard deviation of the response (peak area) and $\mathrm{S}$ is the slope of the calibration curve obtained.

\subsection{Experimental animal model}

In this study, male Wistar rats weighing 220-250 g were used. The rats were randomly assigned into two groups: a control group $(n=18)$ and a group with experimentally induced deep venous thrombosis $(n=18)$. They were housed in cages and maintained in a controlled environment with free access to food and water. The experimental animal model $[3,20]$ of venous thrombosis was induced by ligature of the femoral vein in rats. The hypercoagulability of blood was achieved by the intravenous administration of tissue thrombin $[21,22]$. The rats were anaesthetized by intraperitoneal injection of water solution of Nesdonal (concentration $20 \mathrm{mg} / \mathrm{kg}$ body weight). The i.v. bolus dose of Tirofiban hydrochloride dissolved in sterile saline $(0.6 \mathrm{mg} / \mathrm{kg})$ was given to the rats through tail vein injection. Blood samples were 
taken at $0,5,15,30,45$, and 60 min post-dose in the presence of heparin and were collected in serum tubes. They were centrifuged at $3500 \mathrm{rpm}$ $\mathrm{min}^{-1}$ for $5 \mathrm{~min}$, then serum was harvested and kept at $-20{ }^{\circ} \mathrm{C}$ until analyzed. Then, methanol was added for protein precipitation in the serum : methanol ratio $(1: 3)$. The tubes were then centrifuged again at $3500 \mathrm{rpm} \mathrm{min}{ }^{-1}$ for $5 \mathrm{~min}$ and supernatant was injected into the HPLC column.

\section{RESULTS AND DISCUSSION}

Initial experiments were carried out using the mobile phase consisting of 1-octane sulfonic acid in water and acetonitrile in different proportions and at different $\mathrm{pH}$ values. Mobile phase composition of 1-octane sulfuric acid in water $(\mathrm{pH}$ 3.0, adjusted with orthophosphoric acid) and acetonitrile $(60: 40, \mathrm{v} / \mathrm{v})$ was found to be optimal for good peak resolution for Tirofiban and heparin with a retention time of $8.7 \mathrm{~min}$ and $11.4 \mathrm{~min}$. for Tirofiban and heparin, respectively. The optimum wavelength for detection was $277 \mathrm{~nm}$.

System suitability tests as an integral part of each analytical HPLC methods was performed through evaluation of different parameters (retention time, tailing factor, retention factor, resolution, and selectivity) on freshly prepared standard stock solutions of Tirofiban. The retention times of Tirofiban in methanol and rat serum samples were 8.7 and $8.6 \mathrm{~min}$, respectively. Tailing and retention factors for Tirofiban were obtained as 1.13 and 1.21. Resolution factor for this system for Tirofiban and heparin was 3.50. The variation in retention time of Tirofiban among five replicate injections of standard solution in methanol and rat serum samples was very slight, giving the relative standard deviations (RSD \%) of $0.54 \%$ and $0.73 \%$, respectively.

The calibration characteristics and validation parameters of the proposed method are shown in Table 1. Linearity of response was calculated as a ratio of peak areas of Tirofiban $v s$. concentration in methanol and spiked serum samples in the concentration range of $0.033-0.21 \mathrm{mg} \cdot \mathrm{ml}^{-1}$. Coefficient of correlation was greater than 0.99 for both media.

The results of precision, accuracy (recovery), and reproducibility (assay) of the method are shown in Table 2. They demonstrate a good precision (determined as the RSD \%), accuracy, and reproducibility.

Table 1

Characteristics of the linear regression analysis

\begin{tabular}{lcc}
\hline \hline & Methanol & Rat serum \\
\hline Linearity range $\left(\mathrm{mg} \cdot \mathrm{ml}^{-1}\right)$ & $0.033-0.21$ & $0.033-0.21$ \\
Slope & 3561.1 & 3041.8 \\
Intercept & -13.1235 & -13.9671 \\
Determination coefficient $\left(r^{2}\right)$ & 0.9991 & 0.9983 \\
& 5.8008 & 6.7076 \\
$\mathrm{SE}^{\mathrm{a}}$ of the intercept & 43.4632 & 50.2579 \\
$\mathrm{SE}$ of the slope & 0.0053 & 0.0073 \\
Detection limit $\left(\mathrm{mg} \cdot \mathrm{ml}^{-1}\right)$ & 0.0163 & 0.0221 \\
Quantification limit $\left(\mathrm{mg} \cdot \mathrm{ml}^{-1}\right)$ &
\end{tabular}

asE - Standard error

Table 2

Precision and accuracy of the method

\begin{tabular}{|c|c|c|c|c|c|}
\hline \multirow{4}{*}{$\begin{array}{l}\text { Concentra- } \\
\text { tion added } \\
\left(\mathrm{mg} \cdot \mathrm{ml}^{-1}\right) \\
\end{array}$} & \multicolumn{5}{|c|}{ Measured concentration $\left(\mathrm{mg} \cdot \mathrm{ml}^{-1}\right)^{\mathrm{a}}$} \\
\hline & \multicolumn{2}{|c|}{ In methanol } & \multicolumn{3}{|c|}{ In rat serum } \\
\hline & \multirow{2}{*}{$\begin{array}{c}\text { Intra-day } \\
\text { Mean }\left(\mathrm{mg} \cdot \mathrm{ml}^{-1}\right) \\
\pm \operatorname{RSD}(\%)\end{array}$} & \multirow{2}{*}{$\begin{array}{c}\text { Inter-day } \\
\text { Mean }\left(\mathrm{mg} \cdot \mathrm{ml}^{-1}\right) \\
\pm \operatorname{RSD}(\%)\end{array}$} & \multicolumn{2}{|c|}{ Intra-day } & \multirow{2}{*}{$\begin{array}{c}\text { Inter-day } \\
\text { Mean }\left(\mathrm{mg} \cdot \mathrm{ml}^{-1}\right) \\
\pm \operatorname{RSD}(\%)\end{array}$} \\
\hline & & & $\begin{array}{l}\text { Mean }\left(\mathrm{mg} \cdot \mathrm{ml}^{-1}\right) \\
\quad \pm \operatorname{RSD}(\%)\end{array}$ & Recovery (\%) & \\
\hline 0.033 & $0.0329 \pm 0.96$ & $0.0318 \pm 1.17$ & $0.0315 \pm 1.54$ & 95.45 & $0.0309 \pm 0.87$ \\
\hline 0.100 & $0.1023 \pm 0.67$ & $0.1025 \pm 0.98$ & $0.0985 \pm 1.14$ & 98.50 & $0.0974 \pm 1.75$ \\
\hline 0.211 & $0.2137 \pm 1.13$ & $0.2123 \pm 1.45$ & $0.2045 \pm 1.39$ & 96.92 & $0.2019 \pm 0.93$ \\
\hline
\end{tabular}

a Mean value of five determinations 
Figure 2a shows a typical chromatogram of the extract of the fresh blank serum sample. Figure $2 b$ shows the chromatogram of methanol used as a solvent. Figure $2 \mathrm{c}$ shows a chromatogram of Tirofiban standard solution in methanol, while Figure $2 \mathrm{~d}$ shows a chromatogram of Tirofiban standard solution with heparin in methanol. Figure 2e shows the chromatogram obtained when the same method was applied to spiked rat serum samples. There are no extraneous peaks from endogenous substances in chromatograms obtained in serum samples.

In our previous work [16], with a mobile phase containing of $0.1 \mathrm{M} \mathrm{KH}_{2} \mathrm{PO}_{4}(\mathrm{pH}$ 5.2) and acetonitrile $(70: 30, \mathrm{v} / \mathrm{v})$, the response was linear over the range of $0.03-0.18 \mathrm{mg} \cdot \mathrm{ml}^{-1}$ and the limit of detection (LOD) for Tirofiban in rat serum was $13.8 \mu \mathrm{g} \mathrm{ml}^{-1}$.

In the proposed method, the response was linear over the range of $0.033-0.21 \mathrm{mg} \cdot \mathrm{ml}^{-1}$ and the LOD for Tirofiban in rat serum was twice as high $\left(7.30 \mu \mathrm{g} \mathrm{ml}^{-1}\right)$.

Heparin was detected in both methods, with no reflecting importance, but with significant separation from Tirofiban and without any effect on the calculation of results.

All of the obtained results confirm that the proposed method can be applied in the direct determination of Tirofiban content in the serum. In our study, besides confirmation of the reciprocity of obtained results from the same injected dose in normal rats and rats with introduced experimental deep venous thrombosis, we attempted to present the impact of different concentration of Tirofiban during the same period. This was important to confirm the biodistribution and fast clearance of Tirofiban in both groups and its potential availability to be used as a radioactive marker for the detection and definition of early deep venous thrombosis [23].
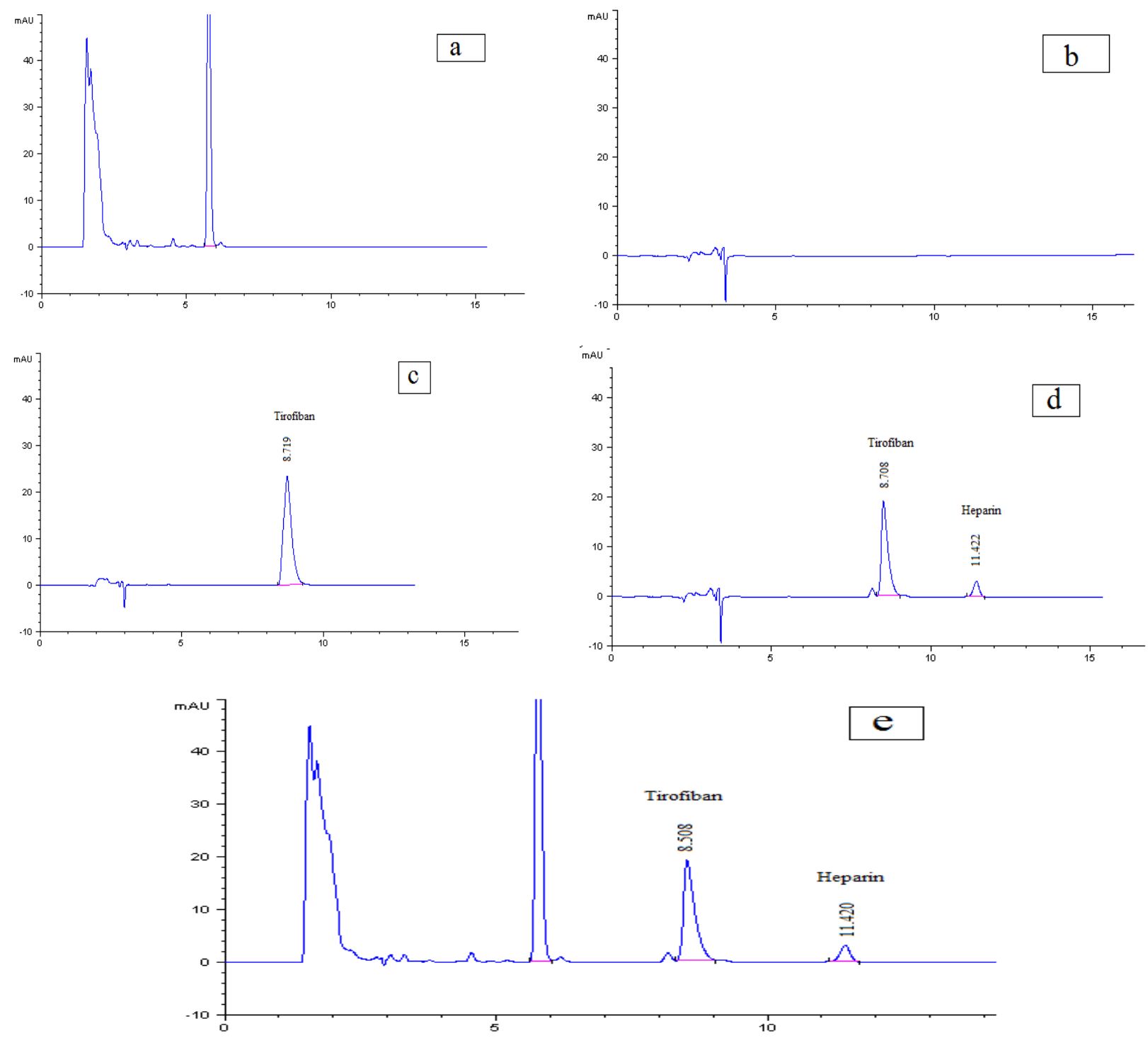

Fig. 2. Chromatograms of blank serum (a), methanol used as solvent (b), Tirofiban in methanol (c), Tirofiban and heparin in methanol (d) and rat serum $5 \mathrm{~min}$ after a single $i . v$. bolus dose of $0.6 \mathrm{mg} / \mathrm{kg}$ Tirofiban (e). 
The low concentration of Tirofiban will not affect the fibrinogen binding to the GPIIb/IIIa receptors, but will be enough to visualize the pathological deviations in the circulation [24]. In Table 2, we present the results obtained by HPLC analysis of the spiked serum samples with Tirofiban. Serum concentrations of Tirofiban $(\mathrm{mg} / \mathrm{l})$ in male rats with and without DVT, after single $i . v$. bolus dose of 0.6 $\mathrm{mg} / \mathrm{kg}$, measured after $5,15,30,45$ and $60 \mathrm{~min}$, determined by HPLC, are shown in Figure 3.

We calculated the percent of Tirofiban as a function of time after i.v. bolus injection. The results are presented in Table 3.

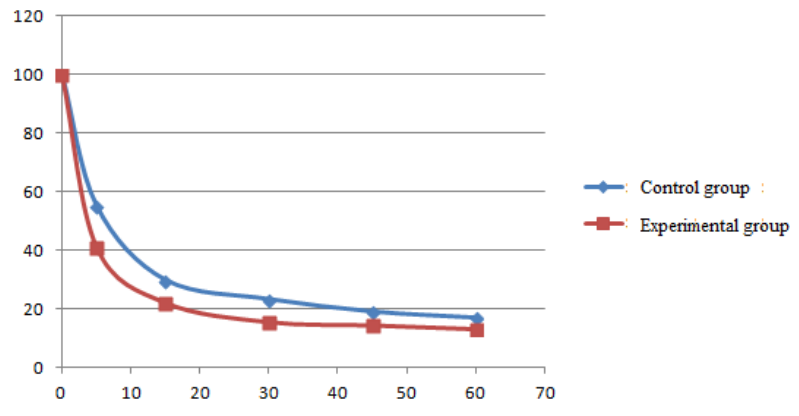

Fig. 3. Concentrations of Tirofiban $(\mathrm{mg} / \mathrm{l})$ in the serum of male rats with and without DVT, after single i.v. bolus dose of $0.6 \mathrm{mg} / \mathrm{kg}$, measured after 5, 15, 30, 45 and $60 \mathrm{~min}$.

T a b le 3

The percent of Tirofiban in the serum of normal rat and rat with DVT after i.v. bolus injection

\begin{tabular}{lcccccc}
\hline \hline Time after injection (min) & 0 & 5 & 15 & 30 & 45 & 60 \\
\hline \multicolumn{7}{c}{ Percent in the serum (\%) after 0.6 mg/kg dose of Tirofiban } \\
\hline Control group & 100,00 & 55,23 & 29,85 & 23,34 & 19,10 & 17,00 \\
Experimental group & 100,00 & 41,21 & 22,24 & 15,67 & 14,55 & 13,27 \\
\hline \hline
\end{tabular}

From the percent presented in Table 3, we can see the difference between samples obtained from normal rats and samples from rats with introduced fresh deep venous thrombosis. The results showed good agreement between two different groups of animals, but not between the different concentrations of injected Tirofiban. Here, $17 \%$ of injected doses found 60 minutes after injection in normal rats and the values of $13.27 \%$ in rats with DVT confirm the fast clearance of Tirofiban from the blood $[14,15]$. Our results confirmed the variability between different concentrations of Tirofiban and its metabolite in human samples, especially those obtained from patients with early DVT [23]. In our study, we did not consider determining the serum concentration in humans, so this will be the goal of our next investigation, after receiving the satisfactory result after the first labeling of Tirofiban with radioactive isotopes [23]. The good correlation in serum concentrations of different concentrations of Tirofiban obtained from experimental animals and from patients with acute DVT, will contribute to the idea that radiolabeled Tirofiban can be introduce as a potential radiopharmaceutical.

\section{CONCLUSION}

The proposed RP-HPLC method is a simple, accurate, precise and rapid for the determination of Tirofiban in the serum. The developed HPLC method was fully validated by evaluation of the validation parameters. Our results confirmed the aim of our study and showed the possibility of monitoring the concentration of Tirofiban in serum during the therapy, either given alone or in the presence of heparin.

In our study we did not envision determining the serum concentration in humans, so this will be the goal of our next investigation, after receiving satisfactory results regarding the first labeling of Tirofiban with radioactive isotopes. Further, we could contribute to the idea that Tirofiban as a GPIIb/IIa antagonist is a potential imaging pharmaceutical.

\section{REFERENCES}

[1] A. Giordano, A. D'Angelillo, S. Romano, P. D'Arrig, N. Corcione, R. Bisogni, S. Messina, M. Polimeno, P. Pepino, P. Ferraro, M. F. Romano, Tirofiban induces VEGF production and stimulates migration and proliferation of endothelial cells, Vascul Pharmacol., 61(2-3), 63-71 (2014).

[2] M. Hashemzadeh, M. Furukawa, S. Goldsberry, M. R. Movahed, Chemical structures and mode of action of intravenous glycoprotein IIb/IIIa receptor blockers: A review, Exp Clin Cardiol., Winter; 13(4), 192-197 (2008).

[3] L. L. Brunton, J. S. Lazo, K. Parker, Goodman and Gilman's The Pharmacological Basis of Therapeutics, $11^{\text {th }}$ ed.; The McGraw Hill Co., 2006.

[4] J. I. Weitz. Blood Coagulation and Anticoagulant, Fibrinolytic, and Antiplatelet Drugs. In: Goodman and Gilman's The Pharmacological Basis of Therapeutics, $12^{\text {th }}$ ed., New York; The McGraw Hill Co, 2011, 849-877. 
[5] A. Kumar, H. C. Herrmann, Tirofiban: an investigational platelet glycoprotein IIb/IIIa receptor antagonist, Exp Opin Invest Drugs, 6, 1257-67 (1997).

[6] The Platelet Receptor Inhibition in Ischemic Syndrome Management in Patients Limited by Unstable Signs and Symptoms (PRISM-PLUS) Study Investigators. Inhibition of the platelet glycoprotein IIb/IIIa receptor with Tirofiban in unstable angina and non-Q-wave myocardial infarction. N Engl J Med, 338, 1488-97 (1998).

[7] The Study Investigators. Effects of platelet glycoprotein IIb/IIIa blockade with Tirofiban on adverse cardiac events in patients with unstable angina or acute myocardial infarction undergoing coronary angioplasty. Circulation, 96, 1445-53 (1997).

[8] L. Brass, Understanding and evaluating platelet function, Hematology Am Soc Hematol Educ Program, 387396 (2010)

[9] http://www.accessdata.fda.gov/drugsatfda_docs/label/20 12/020912s018,0209 13s017lbl.pdf assessed on $24^{\text {th }}$ of October, 2014.

[10] Anon, Tirofiban hydrochloride, Drugs Future, 20, 897 901 (1995).

[11] K. Kondo, K. Umemura, Clinical pharmacokinetics of Tirofiban, a nonpeptide glycoprotein IIb/IIIa receptor antagonist: comparison with the monoclonal antibody abciximab, Clin Pharmacokinet, 41(3), 187-95 (2002).

[12] Medicure Pharma, Aggrastat (Tirofiban hydrochloride) injection premixed and injection prescribing information, Somerset, NJ; Nov. (2007).

[13] http://www.accessdata.fda.gov/drugsatfda_docs/label/20 $12 / 020912 \mathrm{~s} 018,0209$ 13s017lbl. pdf, assessed on 14th of July 2012.

[14] D. W. Bougie, P. R. Wilker, E. D. Wuitschick, B. R. Curtis, M. Malik, S. Levine, R. N. Lind, J. Pereira, R. H. Aster, Acute thrombocytopenia after treatment with Tirofiban or eptifibatide is associated with antibodies specific for ligandoccupied GPIIb/IIIa, Journal of the American Society of Hematology, 100(6), 2071-2076 (2002).
[15] R. Oertel, A. Köhler, A. Koster, W. Kirch, Determination of Tirofiban in human plasma by liquid chromatography-tandem mass spectrometry, J Chromatogr B Analyt Technol Biomed Life Sci., 805(1), 181-5 (2004).

[16] M. Darkovska Serafimovska, E. Janevik-Ivanovska, Z. Arsova-Sarafinovska, I. Djorgoski, N. Ugresic, Development and validation of reversed phase high performance liquid chromatographic method for determination of Tirofiban in serum, Int J Pharm, 4(4), 115-120 (2014).

[17] K. Sridevi Ranjitha, A. Lakshmana Rao, Development and validation of new RP-HPLC method for the determination of Tirofiban in pharmaceutical formulation, IJPCBS, 1(1), 43-47 (2011).

[18] ICH Q2R1: Validation of Analytical Procedures: Text and Methodology. Proceeding of the International Conference on Harmonization of Technical Requirements for the Registration of Drugs for Human Use, Geneva, Switzerland, 1996.

[19] ICH, Guideline on Analytical Method Validation, Proceeding of International Convention on Quality for the Pharmaceutical Industry, Toronto, Canada, 2002.

[20] J. Lister-James, A. Mauer, Thrombus imaging with a technetium $99 \mathrm{~m}$ labeled, activated platelet receptor binding peptide, J. Nucl. Med., 213, 207 (1996).

[21] J. W. Callas, D. D. J. Fareed, A survey of animal models to develop new and novel antithrombotic agents, New Therapeutic Agents in Thrombosis and Thrombolysis (Sasahara, A. A., Loscalzo, J. L., Eds), 1997, 9-28.

[22] J. M. Herbert, A. Bernat, J. P. Maffrand, Importance of platelets in experimental venous thrombosis in the rat, Blood, 80 (9), 2281-2286 (1992).

[23] M. Darkovska Serafimovska, E. Janevik-Ivanovska, N. Ugresic, I. Djorgoski, Imaging of deep venous thrombosis using radioactive-labeled tirofiban. Bratisl Med J, 116 (10), 621-626 (2015).

[24] M. Gibaldi, D. Perrier, Pharmacokinetics, 2nd edition, Marcel Dekker, Inc. New York, USA, 1982. 
